\title{
Mixed species diets enhance the growth of two rocky intertidal herbivores
}

\author{
Kristin M. Aquilino ${ }^{1,2, *}$, Meghan E. Coulbourne ${ }^{2,3}$, John J. Stachowicz ${ }^{1,2}$ \\ ${ }^{1}$ Center for Population Biology, University of California, Davis, California 95616, USA \\ ${ }^{2}$ Bodega Marine Laboratory, Bodega Bay, California 94923, USA \\ ${ }^{3}$ Department of Biology, Hood College, Frederick, Maryland 21701, USA
}

\begin{abstract}
Seaweeds provide food and shelter for countless species of invertebrates. Many studies show how particular species of seaweed facilitate particular invertebrates, but few examine the simultaneous effects of multiple seaweeds, despite the fact that algal composition and diversity are known to vary considerably. We conducted laboratory experiments to determine how algal species richness affected the consumption and growth of 2 common rocky shore herbivores: the turban snail Chlorostoma funebralis and the lined shore crab Pachygrapsus crassipes. For both herbivores, highest growth was achieved on a diet of mixed algal species, though this was greater than growth on the best single species only for $C$. funebralis. However, the herbivores differed in their growth on particular single species diets and consumed prey species at different rates. This suggests that, despite the similar boost in growth achieved by a diverse diet, the exact mechanism was not the same for the 2 species. The benefits were not due simply to inclusion of the best single food species in the mixed diet because consumption of these highest quality foods was lower in mixed than in single species treatments and contributed only $50 \%$ of dietary intake in mixed diet treatments. It seems likely that complementary nutritional quality, chemistry, or morphology among prey species contributed to the positive effects of diet species richness on herbivore performance. Similar findings for taxonomically and ecologically distinct herbivores suggest that such effects of diet species richness on consumer performance may be widespread among marine generalist herbivores.
\end{abstract}

KEY WORDS: Diet mixing · Biodiversity $\cdot$ Consumption $\cdot$ Growth $\cdot$ Herbivory $\cdot$ Macroalgae Rocky intertidal

Resale or republication not permitted without written consent of the publisher

\section{INTRODUCTION}

Seaweed diversity and species composition varies considerably within and across intertidal habitats as a result of spatial variation in physical and biological factors and disturbance (Lubchenco 1978, Sousa 1979a, Airoldi 1998, Benedetti-Cecchi et al. 2001). Particular species of algae can have strong facilitative effects on particular species of invertebrates (Hacker \& Steneck 1990, Bertness et al. 1999), or even the overall diversity of the invertebrate community (Lilley \& Schiel 2006). However, fewer data are available to examine the additive or interactive effects of multiple seaweed species on invertebrate communities (Bates \& DeWreede 2007). Experimental studies from other systems provide evidence that plant species diversity can affect the diversity or abundance of higher trophic level organisms (Siemann 1998, Haddad et al. 2001, Narwani \& Mazumder 2010). The increased diversity of animals in more diverse plant assemblages on land is often attributed to specialized host-plant interactions (Duffy 2002, Ives et al. 2005, Jactel \& Brockerhoff 2007). However, specialists are less common among marine 
than terrestrial invertebrate herbivores (Hay 1991), and thus this mechanism may be of minimal importance in the ocean (Parker et al. 2001). Yet, other mechanisms could still produce an effect of producer diversity on invertebrate communities. For example, enhanced structural complexity in species-rich producer assemblages can lead to reduced predation pressure in more diverse habitat assemblages (Moran et al. 2010). Additionally, the generalist feeding habit of many marine consumers can increase the richness of prey species eaten by a single consumer. If different prey offer complementary nutritional content, this can lead to increased consumer performance on mixed diets (see meta-analysis in Worm et al. 2006). In this paper, we test the effect of single vs. mixed species diet on the growth and survival of 2 rocky intertidal generalist herbivores.

A substantial body of research has examined the consequences of mixed diets for consumers, asking whether consumers generally grow best on monospecific diets of preferred prey or if diet mixing enhances consumer growth (Bernays et al. 1994, Hagele \& Rowell-Rahier 1999, Camus et al. 2008, reviewed for marine organisms in Stachowicz et al. 2007), particularly in aquaculture studies (e.g. Stuart \& Brown 1994, O'Connor \& Heasman 1997, Graham 2008). Mixed diets can increase the performance (e.g. growth or reproductive output) of a variety of marine consumer taxa (Worm et al. 2006) by allowing consumers to benefit from nutritional differences among prey, avoid the cumulative effects of chemical or morphological deterrents, or both (e.g. Pennings et al. 1993, Cruz-Rivera \& Hay 2003). Mixed diets can also boost consumer performance over the average monospecific diet simply because these diets include the most nutritious prey item (e.g. Cruz-Rivera \& Hay 2000), analogous to a sampling effect (see Stachowicz et al. 2007).

On rocky intertidal shores, herbivores generally decrease the abundance of early successional, ephemeral algae, such as Ulva spp., by direct consumption, with positive indirect consequences for the abundance of later successional, perennial species (Lubchenco 1978, Sousa 1984, Aquilino \& Stachowicz 2012). Laboratory feeding studies have shown that herbivores preferentially consume ephemeral algae like Ulva spp. (Arrontes 1990, Barry \& Ehret 1993), arguably because ephemeral algae lack structural or chemical defenses and/or have high nutritional quality. Although selective consumption of ephemeral prey may be adaptive, the limited studies available on rocky shores generally support the idea that mixed diets lead to greater performance (Watanabe
1984, Kennish 1996, Graham 2008). Conducting prey selection experiments in parallel with longer term growth experiments that include the majority of relevant prey items found in the field would help address whether consumer preferences are adaptive. Furthermore, understanding algal effects on herbivores and herbivore effects on algae within the same system might improve our understanding of long-term community dynamics.

We quantified the effects of rocky shore macroalgal species richness and identity on the growth of the 2 most common intertidal macroalgal grazers in north-central California, USA: the black turban snail Chlorostoma (Tegula) funebralis and the lined shore crab Pachygrapsus crassipes. In this system, algal species richness increases the total cover and stability of algal communities (Stachowicz et al. 2008), and seasonally increases the invertebrate community species richness as well as the abundance of particular invertebrate species (J. J. Stachowicz unpubl. data), but the long-term consequences of living in areas of high versus low algal species richness for herbivore growth are not known. The maintenance of perennial algal species diversity by herbivores during community development suggests that understanding effects of diet diversity on herbivore performance could help elucidate potential community level feedbacks (Aquilino \& Stachowicz 2012). We examined how the identity and species richness of algal diet affect growth and survival of C. funebralis and P. crassipes. To understand the potential mechanisms driving the effects of diet diversity on consumer performance, we also examined the nutritional content of each alga and the consumption of each prey species in choice and no-choice experiments.

\section{MATERIALS AND METHODS}

\section{Study system}

The mid-high rocky intertidal zone $(\sim 1 \mathrm{~m}$ above mean lower-low water) on the Bodega Marine Reserve $\left(38^{\circ} 19.0^{\prime} \mathrm{N} 123^{\circ} 41^{\prime} \mathrm{W}\right)$ in northern California is characterized by upwelling and high wave stress (for further details about the physical characteristics of this locality see Sutherland 1970). A diverse assemblage of herbivores inhabits this system. Limpets, such as Lottia scabra and L. digitalis, and the snails Littorina plena, L. scutulata, and Chlorostoma funebralis are the most abundant molluscan grazers at this tidal height, whereas gammarid 
amphipods and the crab Pachygrapsus crassipes are the most common arthropod grazers (Aquilino \& Stachowicz 2012). Of these, we chose to focus on $C$. funebralis and $P$. crassipes because they are both abundant and are known to include macroalgae as a large component of their diet. The $C$. funebralis diet appears to be dominated by macroalgae (Kitting 1978, Morris et al. 1980), which it readily consumes in the lab (e.g. Best 1964), and the high density of this snail (mean $\pm \mathrm{SE}=36 \pm 18 \mathrm{~m}^{-2}$ ) (J. J. Stachowicz unpubl. data) is evidence of its potential impact on algal communities. Although P. crassipes are not easily detected in visual surveys due to their high mobility and their tendency to occur interstitially in mussel beds during daytime low tides, these crabs can occur at densities at least as high as $17 \mathrm{~m}^{-2}$ in destructive surveys of mussel beds in the mid-high zone (M. E. Coulbourne unpubl. data). $P$. crassipes predominantly consumes macroalgae, including red and green algae as a large portion of its diet in the field (Barry \& Ehret 1993) and is known to affect macroalgal species composition in field enclosure experiments in other locations (Sousa 1979b).

Four perennial macroalgal species compose over $85 \%$ of total macroalgal cover on emergent rock and mussel substrate in this zone on the reserve (Stachowicz et al. 2008). These species are the canopyforming brown algae Pelvetiopsis limitata (making up an average of $36 \%$ of the total macroalgal cover), the foliose red algae Mastocarpus papillatus (27\% of total macroalgal cover), the turf-forming red algae Endocladia muricata (17\% of total macroalgal cover), and the turf-forming green algae Cladophora columbiana ( $9 \%$ of total macroalgal cover), all of which have overlapping distributions in the field. The ephemeral species Ulva spp. can be abundant as a seasonal epiphytes or in areas of high disturbance but accounts for an average of only $5 \%$ of total macroalgal cover (Sousa 1984, Aquilino \& Stachowicz 2012). Eight years of sampling in these plots revealed that all 5 seaweeds regularly co-occur in $20 \times 20 \mathrm{~cm}$ quadrats, and thus, all herbivores typically have access to all species. Chlorostoma funebralis and Pachygrapsus crassipes readily consume all of these algal species in laboratory feeding trails (see 'Results'). Although they may consume additional foods in the field (e.g. microalgae), we restricted our study to these food choices because they are the most abundant in the field, and both consumers appear to focus on macroalgal prey based on field observations and lab studies (Best 1964, Kitting 1978, Morris et al. 1980, Barry \& Ehret 1993).

\section{Measuring feeding and growth}

We measured snail and crab growth and consumption rates in the laboratory on 6 different algal diets: Cladophora columbiana, Endocladia muricata, Mastocarpus papillatus, Pelvetiopsis limitata, and Ulva sp. alone, or all 5 species together in mixture. Algae were collected from the north shore of Horseshoe Cove on the Bodega Marine Reserve at $\sim 1 \mathrm{~m}$ tidal height for all experiments. Herbivores were collected at the same location as the algae. We replaced the algae in experimental cages weekly and provided enough of each type so that the herbivores never exhausted any of the species available to them. We also measured growth of herbivores that were given no macroalgae to determine whether performance in any treatment was worse than starvation, which could indicate severe toxic effects of consuming particular species. Using plastic clips and cable ties, we secured algae to the bottom of 0.51 plastic cages with $2 \mathrm{~mm}$ mesh sides. When measuring feeding rates, cages with herbivores and algae were paired with cages containing algae alone to account for changes in algal mass due to factors other than consumption (Roa 1992). Cages were submerged in flowing seawater. To minimize microalgal growth, the experiments were performed indoors on a $12 \mathrm{~h}$ light:12 h dark cycle.

For the Chlorostoma funebralis experiment, each cage contained 3 field collected snails (averaging 9.0 $\pm 0.1 \mathrm{~mm}$ in shell diameter and $0.28 \pm 0.01 \mathrm{~g}$ wet mass) marked with colored nail polish to distinguish individuals. The unit of replication was the cage and there were 10 cages per treatment. The experiment ran for $149 \mathrm{~d}$ from November 2009 to April 2010. Prior to the start of the experiment, we measured the height, diameter, and mass of each snail, and we etched a notch in the outer lip of the body whorl of each snail to measure new shell growth. Because we were interested in whether diets differentially affected snail tissue growth and shell growth, we also weighed the snails suspended in seawater to nondestructively obtain a proxy for change in shell mass alone (Palmer 1982). If the effects of diet on mass change in air were different from change in seawater, this would provide evidence that diet had differential effects on snail tissue and shell growth, and we could use the regression methods of Palmer (1982) to estimate actual tissue and shell mass.

For the Pachygrapsus crassipes experiment, we used only $1 \mathrm{crab}$ per cage to avoid intraspecific predation, which would have changed the composition of their diet. We performed the experiment in 2 
blocks to increase replication: 1 in 2010 ( $\mathrm{N}=10)$ and the other in $2011(\mathrm{~N}=20)$, both lasting from mid-June to mid-September. Two crabs from the Cladophora columbiana and 1 from the Ulva sp. diet treatment escaped during the experiments and were not included in the analyses. Crabs averaging $8.1( \pm 0.1) \mathrm{mm}$ in carapace width were collected from mussel beds in the field. The 5 algal species used in the experiment grew on or within the same vertical zone as the mussel beds and so were available to the grazers as prey prior to collection. To assess crab growth we measured crab carapace width, wet mass (for the 2010 block only), and days to first molt. For analysis, crabs that never molted were assigned a value of days to first molt equal to the duration of the growth experiment $(84 \mathrm{~d})$. Crabs were checked daily to monitor molting and mortality, and molts were removed from cages to prevent their consumption.

We assessed consumption rates on each algal diet 2 wk into the first block of the Pachygrapsus crassipes growth study and at the end of the Chlorostoma funebralis growth study. Total algal biomass was kept constant among treatments for each herbivore, with a total of $2.5 \mathrm{~g}$ of algae in snail cages $(0.5 \mathrm{~g}$ of each species in mixture), and $1.25 \mathrm{~g}$ of algae in crab cages ( $0.25 \mathrm{~g}$ of each species in mixture). These amounts of algae were set to a level that was high enough that herbivores never exhausted any of the species available to them before we were able to replace the algae, but low enough that we could still detect changes in biomass due to consumption. Prior to weighing, field collected algae were rinsed of epiphytes, microinvertebrates, and debris, immersed in seawater for $1 \mathrm{~h}$ to ensure that they were fully hydrated, and spun in a salad spinner to remove excess water. Before any algal species in the mixture was consumed completely (at $11 \mathrm{~d}$ for snails and $9 \mathrm{~d}$ for crabs), we weighed the remaining algae by hydrating and spinning, as above. The change in algal mass in cages with herbivores was corrected for change unrelated to consumption using algal mass changes in paired controls lacking herbivores (Stachowicz \& Hay 1999). We used the mixed diet treatments to assess the relative consumption rates among algal species; we define differential consumption in these choice experiments as 'preference'. Because these consumers often sample small bits of each prey item encountered, aggregate consumption over time is a better indication of preference than other metrics, such as order of consumption (see Manly 1995 or Taplin 2007 for other examples of how to define consumer preference). Preferences of $C$. funebralis for algal species in mixed diets measured at 5 mo in this study were equivalent to those measured immediately after individuals of both species were collected from the field (authors' unpubl. data). In a final feeding trial with $C$. funebralis (after the growth experiment was terminated), we fed all individuals mixed diets to test for variation in preferences among snails with different diet histories.

To assess potential reasons for differences in consumption and performance among algal diets, we analyzed 3 thalli of each of the algal species (Cladophora columbiana, Endocladia muricata, Mastocarpus papillatus, Pelvetiopsis limitata, and Ulva sp.) for carbon $(\mathrm{C})$ and nitrogen $(\mathrm{N})$ content $(\% \mathrm{~N}$ and $\mathrm{C}: \mathrm{N}$ ratios) in 2 different years. Thalli were collected in August 2011 from the same location on the north shore of Horseshoe Cove, where algae and consumers were collected for all feeding and growth experiments. We also report the results of nutrient analyses on thalli collected in May 2009 (all species but Ulva sp.) from the south shore of Horseshoe Cove.

\section{Statistical analysis}

We analyzed total amount of algae consumed and herbivore growth among all diet treatments with 1-way analyses of variance (ANOVA), and applied post hoc Ryan's Q tests to ANOVA results to compare differences in growth and consumption among them, including block (year) to analyze crab growth. We tested model assumptions by plotting the residuals versus the fitted values, and using Levene's test for homogeneity of variance and Shapiro-Wilk's test for normality within and among treatments. We used cage as the unit of replication, averaging consumption and growth across the 3 individuals within each cage in snail experiments to allow identical analyses for both species. Analyzing snail growth as a mixed model with snail within cage as a random factor produced identical results with zero variance explained by the random term. To assess the relative importance of algal species richness and identity on growth, we first performed an a priori contrast between the mixed and single species treatments (richness effect, $\mathrm{df}=1$ ) on the results of 1-way ANOVAs testing the effect of all diet treatments containing algae (i.e. all but the 'starved' treatment) on consumption and growth. We used the residual treatment sums of squares, attributable to variation among the single species treatments $(\mathrm{df}=4)$, to evaluate the effect of species identity (Bruno et al. 2005). We calcu- 
lated magnitude of effects $\left(\omega^{2}\right)$ for algal richness and identity (Graham \& Edwards 2001). We used this approach because we were unable to use the statistical partitions between sampling and complementarity due to the inability to tell what fraction of growth on mixed diet was due to each seaweed species. To assess the extent to which treatment effects on growth could be explained by differences among diets in total consumption rates, we performed an analysis of covariance (ANCOVA) on the effect of diet treatment on growth using total consumption as a covariate. We used a linear correlation and a Spearman's rank correlation to compare the effect of single species diet treatments on crab versus snail growth and consumption. All analyses were performed in R 2.11.1 (R Development Core Team 2010).

\section{RESULTS \\ Effect of diet species richness on growth and survival}

Algal diet affected shell growth (of the outer lip of the body whorl), shell height, shell diameter, and mass of Chlorostoma funebralis (Fig. 1A; ANOVA: $F_{6,63}=241, \mathrm{p}<0.001$ for shell growth; see Table 1 for ANOVA results for other measurements). The relationship between change in snail mass in air and seawater was strong and linear $\left(F_{1,68}=1536, \mathrm{p}<0.0001\right.$, $\left.\mathrm{r}^{2}=0.96\right)$, indicating that diet treatments affected tissue and shell growth similarly. The relationships between growth of the outer lip of the shell and other growth measurements (mass in air and water, height, and width) were also strong and linear, so we focus on shell growth for the rest of the analyses. Partitioning the effects of diet on shell growth among species richness and identity, each contributed significantly to differences in shell growth $\left(\omega^{2}=0.35, F_{1,54}=255, \mathrm{p}<\right.$ 0.001 for species richness and $\omega^{2}=0.64, F_{4,54}=116, \mathrm{p}<$ 0.001 for identity), with an increase in growth on a mixed diet compared to single species diets. Single species diet treatments varied substantially in their effects on snail growth, with fastest growth on Ulva sp. and Mastocarpus papillatus and slowest growth on Cladophora columbiana. However, shell growth was greater on the mixed diet than on any single species $\operatorname{diet}($ Fig. 1A; Ryan's Q: $\mathrm{p}<0.05$ ).

Algal diet also affected Pachygrapsus crassipes' change in carapace width (Fig. $2 \mathrm{~A}_{i} F_{6,170}=18$, $\mathrm{p}<0.001$ ), mass, and the time to first molt (Fig. 2C, Table 2). Partitioning the effects of diet among species richness and identity, each contributed to dif-
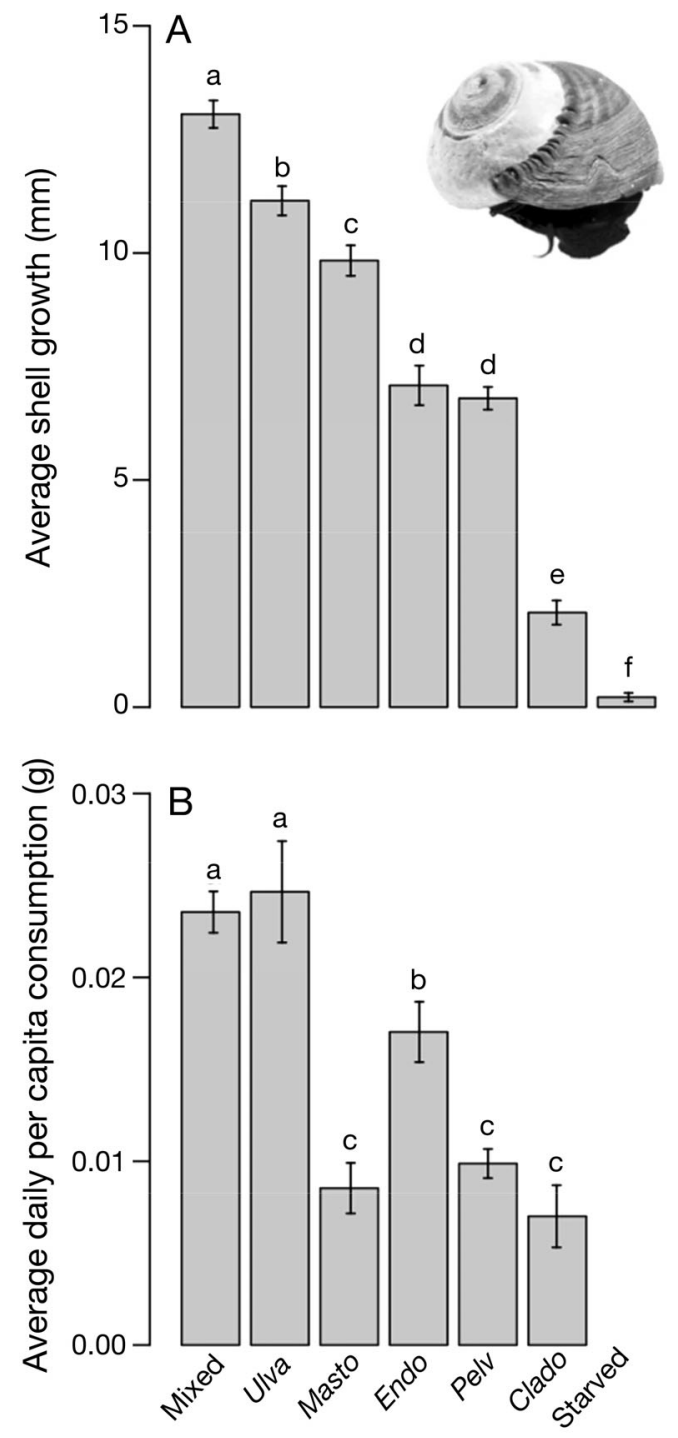

Fig. 1. Chlorostoma funebralis (shown in A). Mean \pm SE (A) growth and (B) daily per capita consumption for each algal diet treatment. Bars with the same letter are not statistically different from each other (Ryan's Q method: $\mathrm{p}>0.05$ ). The abbreviations 'Ulva', 'Masto', 'Endo', 'Pelv', and 'Clado' are for single species diets of Ulva sp., Mastocarpus papillatus, Endocladia muricata, Pelvetiopsis limitata, and Cladophora columbiana, respectively

Table 1. Chlorostoma funebralis growth. Effects of diet treatment on the change in the length of the outer lip of the body whorl (shell growth), mass in air, and mass in seawater ( $\mathrm{df}=6$ for each test). Mass in seawater is a proxy for shell mass alone

\begin{tabular}{|lcc|}
\hline Response & F-ratio & $\mathrm{p}$ \\
\hline Shell growth & 241 & $<0.001$ \\
Mass in air & 117 & $<0.001$ \\
Mass in seawater & 143 & $<0.001$ \\
\hline
\end{tabular}



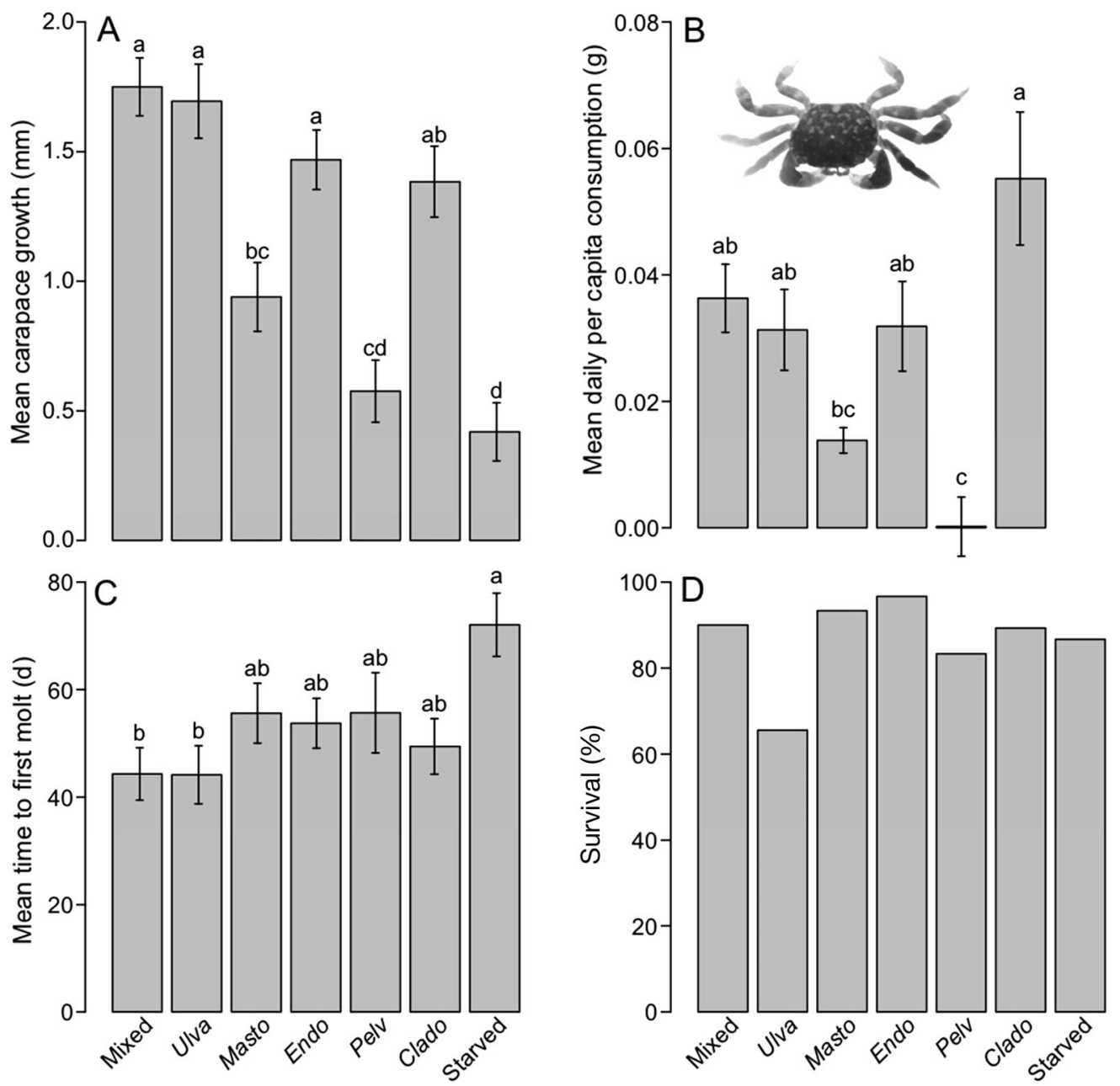

Fig. 2. Pachygrapsus crassipes (shown in B). Mean \pm SE (A) growth, (B) daily per capita consumption for each algal diet treatment, and (C) time to first molt (with $84 \mathrm{~d}$ conservatively assigned to crabs that did not molt). Bars with the same letter are not statistically different from each other (Ryan's Q method: $p>0.05$ ). (D) Percent of crabs in each diet treatment that survived the full growth experiment (84 d). Diet abbreviations are the same as in Fig. 1

ferences in carapace growth $\left(\omega^{2}=0.22, F_{1,145}=15.3\right.$, $\mathrm{p}<0.001$ for richness and $\omega^{2}=0.69, F_{4,145}=12.2$, $\mathrm{p}<0.001$ for identity), with crabs growing more on the mixed diet than single species diets. Among monospecific diet treatments, crabs fed Ulva sp., Endocladia muricata or Cladophora columbiana had the greatest growth and shortest time to first molt.

Table 2. Pachygrapsus crassipes growth: Effects of diet treatment on the change in carapace width, mass, number of days until first molt, and wet mass ( $\mathrm{df}=6$ for each test). Mass measurements are from 2010 only

\begin{tabular}{|lrr|}
\hline Response & F-ratio & \multicolumn{1}{c|}{$\mathrm{p}$} \\
\hline Carapace width & 18.0 & $<0.001$ \\
Mass & 2.6 & 0.025 \\
Time to first molt & 2.7 & 0.015 \\
Survival & 3.0 & 0.008 \\
\hline
\end{tabular}

The increase in carapace width and the time to first molt in the mixed diet treatment did not differ significantly from that in the Ulva sp. treatment (Fig. 2A, $\left.\mathrm{C}_{i} \mathrm{p}>0.05\right)$; however, over 3 times as many crabs died in the Ulva sp. treatment (10 crabs) than in the mixed diet treatment ( 3 crabs; Fig. 2D). Overall, there was no significant difference among treatments in crab survival ( $\mathrm{df}=6, X^{2}=2.1, \mathrm{p}=0.91$ ). The mixed diet did not differ from $C$. columbiana for any particular fitness metric, though crabs consumed more algae on the C. columbiana diet than on any other diet (Fig. 2B).

Although both herbivores grew best on mixed diets, and grew at different rates on different single species diet treatments, there was no correspondence between the growth of crabs and snails among single species diet treatments (linear correlation: $F_{1,3}$ $=0.022, \mathrm{p}=0.89$, Spearman's rank correlation: $\rho=$ 
$0.5, \mathrm{p}=0.45)$. Among the single species diets, both herbivores grew well on Ulva sp., but crabs also grew well on Cladophora columbiana, whereas snails grew the least on this species (Figs. 1A \& 2A).

Because snails and crabs grew least in starved control treatments, and we never saw any accumulation of microalgae in cages, or on the outside of cages, where herbivores could not access, we do not think that microalgae contributed appreciably to herbivore growth in this experiment. Lowest growth in starved treatments also indicated that the potential detrimental effects of noxious chemicals or damaging morphologies in any of the algal species did not outweigh nutritional benefits of the algae for growth.

\section{Effect of diet species richness on consumption}

Total algal consumption varied among diets for both snails (Fig. $1 B_{;} F_{5,54}=21.5, p<0.001$ ) and crabs (Fig. $2 B_{;} F_{5,54}=8.45, \mathrm{p}<0.001$ ). Partitioning the effects of snail diet between algal species richness and identity on total algal consumption, there was an effect of identity $\left(\omega^{2}=0.45, F_{4,54}=19.3, \mathrm{p}<0.001\right)$ and a positive effect of species richness $\left(\omega^{2}=0.18, F_{1,54}=\right.$ $30.4, \mathrm{p}<0.001)$, despite the fact that all snails were initially offered the same total mass of algae and no snails exhausted their supply of any of the available choices. Although total daily per capita consumption by snails was similar between the mixed diet (mean \pm $\mathrm{SE}=0.024 \pm 0.001 \mathrm{~g} \mathrm{~d}^{-1}$ ) and the Ulva sp. treatments $\left(0.025 \pm 0.003 \mathrm{~g} \mathrm{~d}^{-1}\right.$, Ryan's Q: p > 0.05), Ulva sp. accounted for only approximately $50 \%$ of the total algae consumed by snails in the mixed diet treatment (Fig. 3A). For crabs, there was also an effect of algal species identity on consumption $\left(\omega^{2}=0.37, F_{4,54}=\right.$ $10.1, \mathrm{p}<0.001)$, but no effect of richness $\left(\omega^{2}<0.01\right.$, $F_{1,54}=1.87, \mathrm{p}=0.177$ ), indicating that consumption varied among species, but consumption in mixed diet treatments was not different from that in the average monospecific diet.

As with performance, relative consumption rates of different seaweeds varied between the 2 consumers. There was no relationship between total consumption by snails and crabs in single species diet treatments (linear regression: $F_{1,3}=0.016, \mathrm{p}=0.91$, Spearman's rank correlation: $\rho=0.5, p=0.45$ ). Among the single species diets, snails consumed most on the Ulva sp. diet, whereas crabs consumed most on the Cladophora columbiana diet (Figs. 1B \& 2B).

In a final feeding trial with Chlorostoma funebralis (after the 5 mo growth experiment was terminated), preferences were identical to those from earlier in
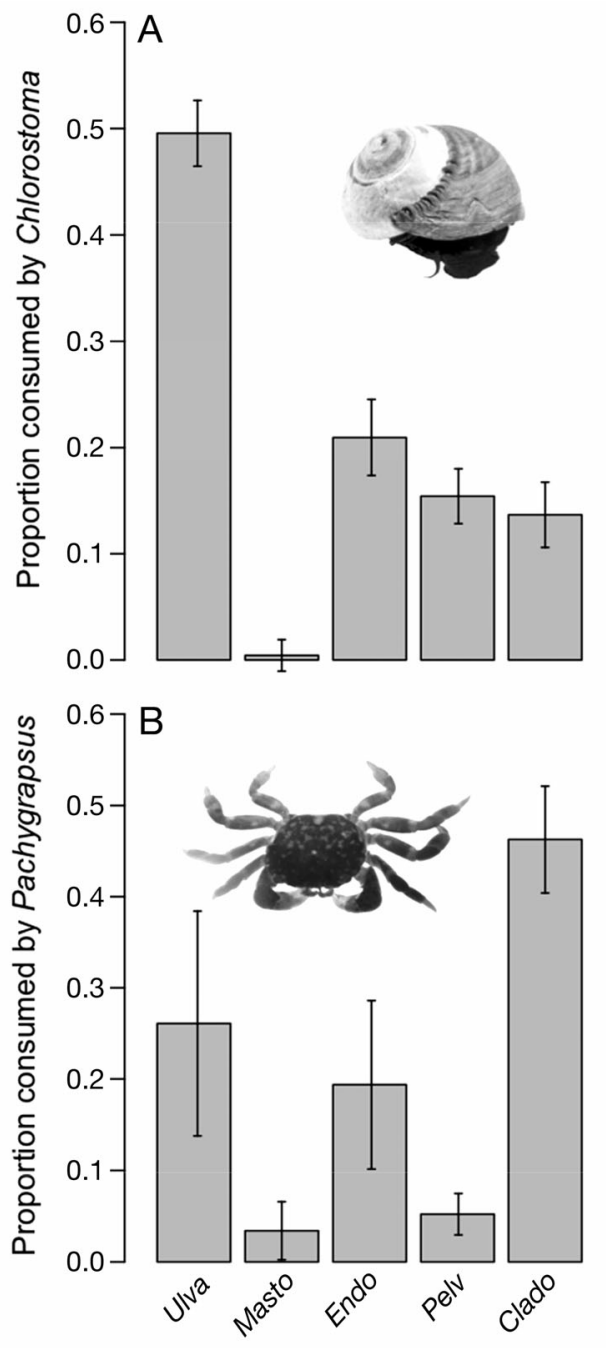

Fig. 3. Mean \pm SE preference in the mixed diet treatment (proportion of each algal species consumed) for (A) Chlorostoma funebralis and (B) Pachygrapsus crassipes. Species shown in panels. Diet abbreviations are the same as in Fig. 1

the experiment, and we found no evidence that diet conditioning might affect preference.

\section{Relationship between preference and growth}

Preference among algal species in mixed diet treatments (Fig. 3) was positively related to the per capita consumption rates in monospecific treatments for snails $\left(\beta=1.3, F_{1,48}=52, \mathrm{p}<0.0001\right)$ and crabs ( $\beta=0.4, F_{1,48}=33, \mathrm{p}<0.0001$, for the 2010 block when both consumption and growth were measured). There was also a positive relationship between consumption in the mixed diet treatments and shell growth on single species diets of snails $\left(\beta=8.2, F_{1,48}\right.$ $=10, \mathrm{p}=0.002$ ) and between preference and cara- 
Table 3. Algal nutritional content. Mean (SE) percent tissue carbon $(\% \mathrm{C})$ and nitrogen (\%N) of dry mass and carbon to nitrogen ratio (C:N) of 3 individuals of each algal species collected from the Bodega Marine Reserve. In May 2009, thalli were collected from the south shore of Horseshoe Cove. In August 2011, thalli were collected from the north shore of Horseshoe Cove, overlapping where algae and consumers were collected for feeding and growth experiments

\begin{tabular}{|c|c|c|c|c|c|c|}
\hline \multirow{2}{*}{ Algal species $(n=3)$} & \multicolumn{3}{|c|}{ - May 2009} & \multicolumn{2}{|c|}{ - August 2011} & \multirow[b]{2}{*}{$\mathrm{C}: \mathrm{N}$} \\
\hline & $\% \mathrm{C}$ & $\% \mathrm{~N}$ & $\mathrm{C}: \mathrm{N}$ & $\% \mathrm{C}$ & $\% \mathrm{~N}$ & \\
\hline Cladophora columbiana & $17.4(0.86)$ & $2.4(0.10)$ & $7.2(0.08)$ & $16.9(1.00)$ & $2.1(0.06)$ & $8.1(0.47)$ \\
\hline Endocladia muricata & $39.0(0.18)$ & $3.6(0.05)$ & $10.8(0.20)$ & $39.0(0.27)$ & $4.1(0.02)$ & $9.6(0.07)$ \\
\hline Mastocarpus papillatus & $33.6(1.34)$ & $3.4(0.18)$ & $10.0(0.20)$ & $32.3(0.32)$ & $3.1(0.07)$ & $10.6(0.21)$ \\
\hline Pelvetiopsis limitata & $35.3(0.26)$ & $1.7(0.04)$ & $20.3(0.50)$ & $35.0(0.49)$ & $1.6(0.15)$ & $22.1(2.01)$ \\
\hline Ulva sp. & - & - & - & $36.6(0.95)$ & $5.3(0.15)$ & $6.9(0.08)$ \\
\hline
\end{tabular}

pace growth for $\operatorname{crabs}\left(\beta=1.3, F_{1,48}=6.7, \mathrm{p}=0.013\right)$. However, performance on some diets deviated considerably from the predicted relationship. For example, snails had the highest growth on their most (Ulva sp.) and least (Mastocarpus papillatus) consumed species (Figs. 1A \& 3A). Furthermore, differences in growth among all algal treatments were significant even when accounting for differences in total algae consumed across single species and mixed diet treatments (ANCOVA: $F_{6,63}=247, \mathrm{p}<0.001$ for snails; $F_{6,63}=9.18$, p $<0.001$ for crabs in 2010), indicating factors other than total or relative consumption rates, such as algal nutritional value or ease of ingestion or digestion, affected growth.

\section{Algal nutritional content}

Ulva sp. had the highest percent nitrogen $(\% \mathrm{~N})$ per dry mass of any of the 5 algal species (Table $3 ; 5.3 \pm$ $0.15 \%)$, and the lowest ratio of carbon to nitrogen (6.9 \pm 0.08). Cladophora columbiana, Endocladia muricata, and Mastocarpus papillatus had intermediate $\% \mathrm{~N}$ content and $\mathrm{C}: \mathrm{N}$, and Pelvetiopsis limitata had the lowest $\% \mathrm{~N}(1.6 \pm 0.15)$ and highest C:N (22.1 \pm 2.01). Although $\mathrm{C}$ and $\mathrm{N}$ contents in algae can vary temporally, the values for $\% \mathrm{~N}, \% \mathrm{C}$, and $\mathrm{C}: \mathrm{N}$ obtained from samples taken in May 2009 and August 2011 were similar to each other (Table 3) and to values in literature (Fujita et al. 1989, Neighbors \& Horn 1991, Wheeler \& Björnsäter 1992, Van Alstyne et al. 2009), so they likely adequately represent relative differences among algae in these nutritional parameters.

\section{DISCUSSION}

We found that diet mixing enhances the growth of 2 common intertidal herbivores, Chlorostoma funebralis and Pachygrapsus crassipes. The similarity of the results between 2 herbivores with very distinct feeding morphologies, physiologies, and feeding preferences suggests that this finding could be general across many consumers in this system. Because we held the total amount of algae offered to each herbivore constant, the amount of each algal species consumed was less in mixture than in the corresponding single species diet treatments (the most preferred species composed, at most, $50 \%$ of diet in mixtures). As a result, the greater performance of herbivores on mixed diets was not solely the result of including a single high-quality food, but was instead likely due to complementarity among algal species in nutritional benefit or dilution of algal chemical or morphological features that negatively impact herbivore fitness (Kitting 1980, Pennings et al. 1993, CruzRivera \& Hay 2003). Crabs preferred and had the highest growth on Cladophora columbiana and Ulva sp.. Because $72 \%$ of the total consumption in mixed diet treatments was of these 2 species, the mixing of these 2 species may be important for crabs. Differences in micronutrients or other aspects of algal nutritional content could drive potential complementarity effects for both herbivores (e.g. Raubenheimer et al. 2005). Additionally, herbivore-deterrent chemistry or morphology that can reduce performance in some herbivore species, such as phenolics in Pelvetiopsis limitata and dimethylsulfoniopropionate in Ulva spp. (Kitting 1980, Steinberg 1985, Van Alstyne et al. 1999, 2009), could be less harmful when diluted in mixed diets. Our experiments did not explicitly test for the mechanisms underlying this complementarity, but we will discuss possible characteristics of the algae that might underlie this effect.

The specific nature of the complementarity that contributes to the benefit provided by a mixed diet are likely different for each herbivore species, because each consumer preferred different algal species. However, both Cladophora columbiana, which was most preferred by Pachygrapsus crassipes, and 
Ulva sp., which was most preferred by Chlorostoma funebralis, have the lowest C:N (Table 3), and nitrogen content has been shown to enhance herbivore consumption and performance (Kiørboe 1989, Van Alstyne et al. 2009). These algae are also both relatively soft and may be consumed with less effort, although we lack data to quantify this. Both species' high consumption of Ulva sp. is also consistent with experimental results demonstrating large effects of herbivores on the abundance of Ulva spp. and similar species in the field (Lubchenco 1978, Sousa 1979b, 1984, Aquilino \& Stachowicz 2012). Curiously, C. funebralis grew nearly as well on Mastocarpus papillatus as it did on Ulva sp., but had the lowest preference for M. papillatus in mixed diets, possibly due to a combination of high nutritional value and morphological deterrents, such as differences in toughness (Thornber et al. 2008). It is possible, for example, that the low rate of consumption of $M$. papillatus was due to its toughness, or because grazing was primarily on reproductive structures of low mass but potentially high nutritional reward (e.g. Thornber et al. 2006). In general, consumers ate more of the species that conferred the most growth, indicating that consumer choices may be adaptive.

Although principally an herbivore, Pachygrapsus crassipes also occasionally consumes animals (Barry \& Ehret 1993), and some grapsid crabs are known to require animal matter for optimal growth (McTigue \& Zimmerman 1991, Kennish 1996). A preference for invertebrates could explain P. crassipes' high consumption of Cladophora columbiana, which contains 4-5 times the abundance and biomass of infaunal microinvertebrates compared to other common algal species (Bracken et al. 2007). In southern California, $P$. crassipes also consumes turf-forming coralline algae that harbor invertebrates, which could be an important nutritional part of its diet, even though coralline algae occurs at low abundances in the zone we examined (Barry \& Ehret 1993). Morphology may also be important in determining herbivore preferences for C. columbiana and other algal species. The thin filaments of $C$. columbiana may be relatively easy for crabs to clip off with their chelae and 'chew' with their mouthparts, whereas they may be very difficult for snails to scrape with their radula.

In our study, snails fed mixed diets had highest performance even for a single fitness metric (growth). In several other studies, effects of species richness are strongest when multiple fitness parameters are measured and integrated, because different monocultures maximize different parameters (e.g. growth, survival, reproduction; reviewed in Stachowicz et al.
2007). Similarly, examining a single metric (growth) across multiple herbivores, our results show that the single species that contribute to the boost in growth in mixtures do not appear to be same for snails and crabs. Examining additional metrics of fitness for each species would prove informative, but the life span and life history of these herbivores is such that these could not be assessed in this study.

Our study demonstrates the potential benefits of diet mixing for 2 distinct herbivores. There is evidence from other marine species, such as gammarid amphipods, that diet mixing is important (Poore \& Hill 2006, reviewed in Stachowicz et al. 2007), thus this potential may be widespread, even in systems with generalist consumers, where specialized host-plant interactions do not drive diversity effects. Whether such benefits are realized in the field is likely dependent on a number of factors not examined in this study, including how spatial and temporal variation in herbivore and algal densities could alter relative and absolute consumption rates of the various algal species. Determining diet under natural conditions is a difficult issue, and there are few data available to assess the degree to which these herbivores actively consume a mixed diet under field conditions.

If the effects of prey diversity on consumer fitness influence consumer distribution and abundance, this could lead to important potential feedbacks between algae and herbivores that facilitate biodiversity maintenance. The high consumption rate of and preference for Ulva sp. by Chlorostoma funebralis, and resulting high herbivore growth rates, suggest that high consumption rates of Ulva spp. observed in rocky shore field experiments (Lubchenco 1978, Sousa 1984, Aquilino \& Stachowicz 2012) may enhance growth of some herbivores seasonally or in recently disturbed areas, where Ulva spp. are abundant (Sousa 1979a, Cubit 1984). Because consumption of Ulva spp. and other ephemeral algal species in disturbed patches tends to accelerate recovery to more diverse algal assemblages (Lubchenco 1978, Aquilino \& Stachowicz 2012), herbivores may increase species richness of algal standing stock (Lubchenco 1978, Worm et al. 2002), leading to the availability of a more diverse diet that ultimately promotes their continued growth. Even for herbivores with poor survival on diets of Ulva spp. alone, like Pachygrapsus crassipes, temporary consumption of Ulva spp. could directly facilitate short-term growth and indirectly facilitate long-term growth and survival by accelerating algal succession and promoting algal species richness. Combined with the lower impact of consumers on total prey abundance in 
diverse prey assemblages (Edwards et al. 2010), this suggests that there may be feedbacks between herbivores and algae that contribute to the maintenance of rocky shore algal species richness. However, such feedbacks could be limited, because the effects of herbivores on algal communities depend on herbivore density and disturbance frequency. Also, broad dispersal of the larvae of these herbivores may restrict these feedbacks to a single generation, since larvae of these crabs and snails likely travel great distances. Nonetheless, the positive impact of species richness on consumer performance across a number of systems and taxa (e.g. Bernays et al. 1994, Hagele \& Rowell-Rahier 1999, Stachowicz et al. 2007) suggests these feedbacks are worth investigation.

Acknowledgements. We thank K. Martens, R. Wong, E. Potter, and E. Hinman for help maintaining experiments. NSF provided funding through grant 0850707 to J.S., a graduate research fellowship to K.M.A., and grant DBI-0753226 to S. Williams and E. Sanford. We thank E. Sanford, T. Grosholz, L. Airoldi and 2 anonymous reviewers for helpful comments on this manuscript.

\section{LITERATURE CITED}

Airoldi L (1998) Roles of disturbance, sediment stress, and substratum retention on spatial dominance in algal turf. Ecology 79:2759-2770

> Aquilino KM, Stachowicz JJ (2012) Seaweed richness and herbivory increase rate of community recovery from disturbance. Ecology 93:879-890

Arrontes J (1990) Diet, food preference and digestive efficiency in intertidal isopods inhabiting macroalgae. J Exp Mar Biol Ecol 139:231-249

Barry J, Ehret M (1993) Diet, food preference, and algal availability for fishes and crabs on intertidal reef communities in southern California. Environ Biol Fishes 37: 75-95

Bates CR, DeWreede RE (2007) Do changes in seaweed biodiversity influence associated invertebrate epifauna? J Exp Mar Biol Ecol 344:206-214

> Benedetti-Cecchi L, Pannacciulli F, Bulleri F, Moschella P, Airoldi L, Relini G, Cinelli F (2001) Predicting the consequences of anthropogenic disturbance: large-scale effects of loss of canopy algae on rocky shores. Mar Ecol Prog Ser 214:137-150

> Bernays EA, Bright KL, Gonzalez N, Angel J (1994) Dietary mixing in a generalist herbivore: tests of two hypotheses. Ecology 75:1997-2006

Bertness MD, Leonard GH, Levine JM, Schmidt PR, Ingraham AO (1999) Testing the relative contribution of positive and negative interactions in rocky intertidal communities. Ecology 80:2711-2726

Best B (1964) Feeding activities of Tegula funebralis (Mollusca: Gastropoda). Veliger 6(Suppl):42-45

> Bracken MES, Gonzalez-Dorantes CA, Stachowicz JJ (2007) Whole-community mutualism: associated invertebrates facilitate a dominant habitat-forming seaweed. Ecology
88:2211-2219

Bruno JF, Boyer KE, Duffy JE, Lee SC, Kertesz JS (2005) Effects of macroalgal species identity and richness on primary production in benthic marine communities. Ecol Lett 8:1165-1174

Camus P, Daroch K, Opazo L (2008) Potential for omnivory and apparent intraguild predation in rocky intertidal herbivore assemblages from northern Chile. Mar Ecol Prog Ser 361:35-45

Cruz-Rivera E, Hay ME (2000) The effects of diet mixing on consumer fitness: macroalgae, epiphytes, and animal matter as food for marine amphipods. Oecologia 123: $252-264$

> Cruz-Rivera E, Hay ME (2003) Prey nutritional quality interacts with chemical defenses to affect consumer feeding and fitness. Ecol Monogr 73:483-506

Cubit JD (1984) Herbivory and the seasonal abundance of algae on a high intertidal rocky shore. Ecology 65: 1904-1917

> Duffy JE (2002) Biodiversity and ecosystem function: the consumer connection. Oikos 99:201-219

Edwards KF, Aquilino KM, Best RJ, Sellheim KL, Stachowicz JJ (2010) Prey diversity is associated with weaker consumer effects in a meta-analysis of benthic marine experiments. Ecol Lett 13:194-201

Fujita RM, Wheeler PA, Edwards RL (1989) Assessment of macroalgal nitrogen limitation in a seasonal upwelling region. Mar Ecol Prog Ser 53:293-303

Graham MH (2008) Integrated culture of seaweeds and red abalone in Monterey Harbor. California Sea Grant Final Project Report. California Sea Grant College Program, University of California, San Diego, CA

> Graham MH, Edwards MS (2001) Statistical significance versus fit: estimating the importance of individual factors in ecological analysis of variance. Oikos 93:505-513

Hacker SD, Steneck RS (1990) Habitat architecture and the abundance and body-size-dependent habitat selection of a phytal amphipod. Ecology 71:2269-2285

Haddad NM, Tilman D, Haarstad J, Ritchie M, Knops JMH (2001) Contrasting effects of plant richness and composition on insect communities: a field experiment. Am Nat 158:17-35

- Hagele BF, Rowell-Rahier M (1999) Dietary mixing in three generalist herbivores: nutrient complementation or toxin dilution? Oecologia 119:521-533

Hay ME (1991) Marine-terrestrial contrasts in the ecology of plant chemical defenses against herbivores. Trends Ecol Evol 6:362-365

Ives AR, Cardinale BJ, Snyder WE (2005) A synthesis of subdisciplines: predator-prey interactions, and biodiversity and ecosystem functioning. Ecol Lett 8:102-116

Jactel H, Brockerhoff EG (2007) Tree diversity reduces herbivory by forest insects. Ecol Lett 10:835-848

Kennish R (1996) Diet composition influences the fitness of the herbivorous crab Grapsus albolineatus. Oecologia 105:22-29

Kiørboe T (1989) Phytoplankton growth rate and nitrogen content: implications for feeding and fecundity in a herbivorous copepod. Mar Ecol Prog Ser 55:229-234

Kitting CL (1978) Foraging of individuals within the limpet species, Acmaea (Notoacmea) scutum at Monterey Bay, California, and the consequence on their mid-intertidal algal foods. PhD dissertation, Stanford University, Stanford, CA

Kitting CL (1980) Herbivore-plant interactions of individual 
limpets maintaining a mixed diet of intertidal marine algae. Ecol Monogr 50:527-550

Lilley SA, Schiel DR (2006) Community effects following the deletion of a habitat-forming alga from rocky marine shores. Oecologia 148:672-681

Lubchenco J (1978) Plant species diversity in a marine intertidal community: importance of herbivore food preference and algal competitive abilities. Am Nat 112:23-39

Manly BFJ (1995) Measuring selectivity from multiple choice feeding-preference experiments. Biometrics 51:709-715

McTigue TA, Zimmerman RJ (1991) Carnivory vs. herbivory in juvenile Penaeus setiferus (Linnaeus) and Penaeus aztecus (Ives). J Exp Mar Biol Ecol 151:1-16

Moran ER, Reynolds PL, Ladwig LM, O'Connor MI, Long ZT, Bruno JF (2010) Predation intensity is negatively related to plant species richness in a benthic marine community. Mar Ecol Prog Ser 400:277-282

Morris RH, Abbott DP, Haderlie EC (1980) Intertidal invertebrates of California. Stanford University Press, Stanford, CA

Narwani A, Mazumder A (2010) Community composition and consumer identity determine the effect of resource species diversity on rates of consumption. Ecology 91: 3441-3447

$>$ Neighbors MA, Horn MH (1991) Nutritional quality of macrophytes eaten and not eaten by two temperate zone herbivorous fishes: a multivariate comparison. Mar Biol 108:471-476

O'Connor WA, Heasman MP (1997) Diet and feeding regimens for larval doughboy scallops, Mimachlamys asperrima. Aquaculture 158:289-303

Palmer AR (1982) Growth in marine gastropods: a nondestructive technique for independently measuring shell and body weight. Malacologia 23:63-73

Parker JD, Duffy JE, Orth RJ (2001) Plant species diversity and composition: experimental effects on marine epifaunal assemblages. Mar Ecol Prog Ser 224:55-67

> Pennings SC, Nadeau MT, Paul VJ (1993) Selectivity and growth of the generalist herbivore Dolabella auricularia feeding upon complementary resources. Ecology 74 : 879-890

Poore A, Hill N (2006) Sources of variation in herbivore preference: among-individual and past diet effects on amphipod host choice. Mar Biol 149:1403-1410

R Development Core Team (2010) R: a language and environment for statistical computing. R Foundation for Statistical Computing, Vienna

Raubenheimer D, Zemke-White WL, Phillips RJ, Clements KD (2005) Algal macronutrients and food selection by the omninvorous marine fish Girella tricuspidata. Ecology 86:2601-2610

Roa R (1992) Design and analysis of multiple-choice feeding-preference experiments. Oecologia 89:509-515

Siemann E (1998) Experimental tests of effects of plant productivity and diversity on grassland arthropod diversity. Ecology 79:2057-2070

Sousa WP (1979a) Disturbance in marine intertidal boulder

Editorial responsibility: Laura Airoldi,

Ravenna, Italy fields: the nonequilibrium maintenance of species diversity. Ecology 60:1225-1239

Sousa WP (1979b) Experimental investigations of disturbance and ecological succession in a rocky intertidal algal community. Ecol Monogr 49:227-254

Sousa WP (1984) Intertidal mosaics: patch size, propagule availability, and spatially variable patterns of succession. Ecology 65:1918-1935

Stachowicz JJ, Hay ME (1999) Reduced mobility is associated with compensatory feeding and increased diet breadth of marine crabs. Mar Ecol Prog Ser 188:169-178

Stachowicz JJ, Bruno JF, Duffy JE (2007) Understanding the effects of marine biodiversity on communities and ecosystems. Annu Rev Ecol Evol Syst 38:739-766

> Stachowicz JJ, Graham M, Bracken MES, Szoboszlai AI (2008) Diversity enhances cover and stability of seaweed assemblages: the role of heterogeneity and time. Ecology 89:3008-3019

Steinberg PD (1985) Feeding preferences of Tegula funebralis and chemical defenses of marine brown algae. Ecol Monogr 55:333-349

Stuart MD, Brown MT (1994) Growth and diet of cultivated black-footed abalone, Haliotis iris (Martyn). Aquaculture 127:329-337

Sutherland JP (1970) Dynamics of high and low populations of the limpet, Acmaea scabra (Gould). Ecol Monogr 40: 169-188

> Taplin RH (2007) Experimental design and analysis to investigate predator preferences for prey. J Exp Mar Biol Ecol 344:116-122

> Thornber C, Stachowicz JJ, Gaines S (2006) Tissue type matters: selective herbivory on different life history stages of an isomorphic alga. Ecology 87:2255-2263

Thornber CS, Jones E, Stachowicz JJ (2008) Differences in herbivore feeding preferences across a vertical rocky intertidal gradient. Mar Ecol Prog Ser 363:51-62

> Van Alstyne KL, McCarthy JJ III, Hustead CL, Duggins DO (1999) Geographic variation in polyphenolic levels of Northeastern Pacific kelps and rockweeds. Mar Biol 133: 371-379

- Van Alstyne KL, Pelletreau KN, Kirby A (2009) Nutritional preferences override chemical defenses in determining food choice by a generalist herbivore, Littorina sitkana. J Exp Mar Biol Ecol 379:85-91

> Watanabe JM (1984) Food preference, food quality and diets of three herbivorous gastropods (Trochidae: Tegula) in a temperate kelp forest habitat. Oecologia 62:47-52

> Wheeler PA, Björnsäter BR (1992) Seasonal fluctuations in tissue nitrogen, phosphorus, and N:P for five macroalgal species common to the Pacific Northwest coast. J Phycol 28:1-6

Worm B, Lotze HK, Hillebrand H, Sommer U (2002) Consumer versus resource control of species diversity and ecosystem functioning. Nature 417:848-851

> Worm B, Barbier EB, Beaumont N, Duffy JE, and others (2006) Impacts of biodiversity loss on ocean ecosystem services. Science 314:787-790

Submitted: October 14, 2011; Accepted: June 20, 2012

Proofs received from author(s): October 3, 2012 